\title{
ROLE OF LARGER FARMS IN POLAND AND SELECTED EUROPEAN UNION COUNTRIES IN 2005 AND 2016
}

\author{
Wojciech Józwiak, Full Professor'; Zofia Mirkowska, MSc²; Wojciech Ziętara, \\ Full Professor ${ }^{3}$
}

Institute of Agricultural and Food Economics National Research Institute

\begin{abstract}
The rates of increase in labour costs in non-agricultural sections and prices of means of production for agriculture, which are higher than selling prices of agricultural products in countries with a market economy have resulted in a decrease in unit profitability of agricultural production. Farmers wishing to obtain a satisfactory income must increase their production scale, mainly by increasing farm area. The study covers two intentionally selected groups of countries differing with regard to economic development specified by gross domestic product (GDP) value per capita. The reason for this selection is the dependence of the farms' economic strength on the national economy level of analysed countries. The first group of countries with a high level of this indicator (GDP) includes: Denmark, Sweden, Ireland, the Netherlands, Austria, Germany, Belgium, Great Britain and France. The second group covers - Slovenia, the Czech Republic, Slovakia, Lithuania, Latvia, Poland, Hungary, Romania and Bulgaria. Analyses covered the changes in average farm area, share of farms with an area of 30 ha of UAA or more in the total number of farms, land use, employment and standard production in 2005 and 2016. In both groups, the following increased in the analysed period: the average farm area and share of larger farms in land use and production. In the majority of analysed countries, the share of farms with an area of 100 ha or more, when it comes to production, exceeded $50 \%$.
\end{abstract}

Keywords: farms, UAA, agricultural production JEL codes: O13, Q12, Q18

\section{INTRODUCTION}

Farms are affected by two types of 'forces'. The theory of forces affecting farms was developed by the German agricultural economist Theodor Brinkmann (Brinkmann, 1922). He distinguished two types: 'Integrierte Kräfte' and 'Diferenzierte Kräfte'. The first type means the integrating forces inside the farm. They make the farm conduct multilateral production in order to make even and full use of land, work and technical means. Differentiating forces, on the other hand, are what constitute the environment which consists of the supply and outlet market as well as the institutions which create so-called farm operation

${ }^{1}$ Corresponding author: Świętokrzyska 20,00-002 Warsaw, jozwiak@ierigz.waw.pl, +4822 5054599

${ }^{2}$ Corresponding author: Świętokrzyska 20,00-002 Warsaw, zmirkowska@ierigz.waw.pl, +4822 5054584

${ }^{3}$ Corresponding author: Świętokrzyska 20,00-002 Warsaw, zietara@ierigz.waw.pl, +4822 5054456 
rules. Recipients of agricultural products, agricultural trade and processing enterprises demand many uniform raw materials of specified quality and size from suppliers. In order to meet these requirements, farmers are forced to specialise in production, as well as increase the intensity level, and, in the longer term, also increase farm area. Trends in the evolution of labour costs in the national economy, the prices of means of production purchased by farmers and the selling prices of agricultural products also have a significant impact on farmers' decisions. Labour costs in the national economy (their main component being salaries) indirectly influence labour costs in agriculture. The trends in the evolution of these costs and selling prices of agricultural products are shown in Figure 1.

During the analysed period (1995-2016), the labour costs in the national economy rose almost six-fold; the prices of means of production purchased by farmers rose more than three-fold and the selling prices of agricultural products more than doubled. The price scissors index during this period was around $70 \%$, which means that the rate of the rise in the prices of means of production for agriculture was by $30 \%$ higher than the rate of increase in the selling prices of agricultural products and resulted in a decrease in production profitability.

Another significant factor influencing farmers' decisions is technical progress, manifesting itself in an increase in tractor power and efficiency of machinery. The rational use of these means causes farmers to increase farm area. These trends make farmers reorganise activities in the ever-changing farming conditions, mainly by increasing farm area and production intensity level. Hence, there is a need to study the role of larger farms. The increase in farm size is a result of the disappearance of poorly managed farms or those lacking successors.

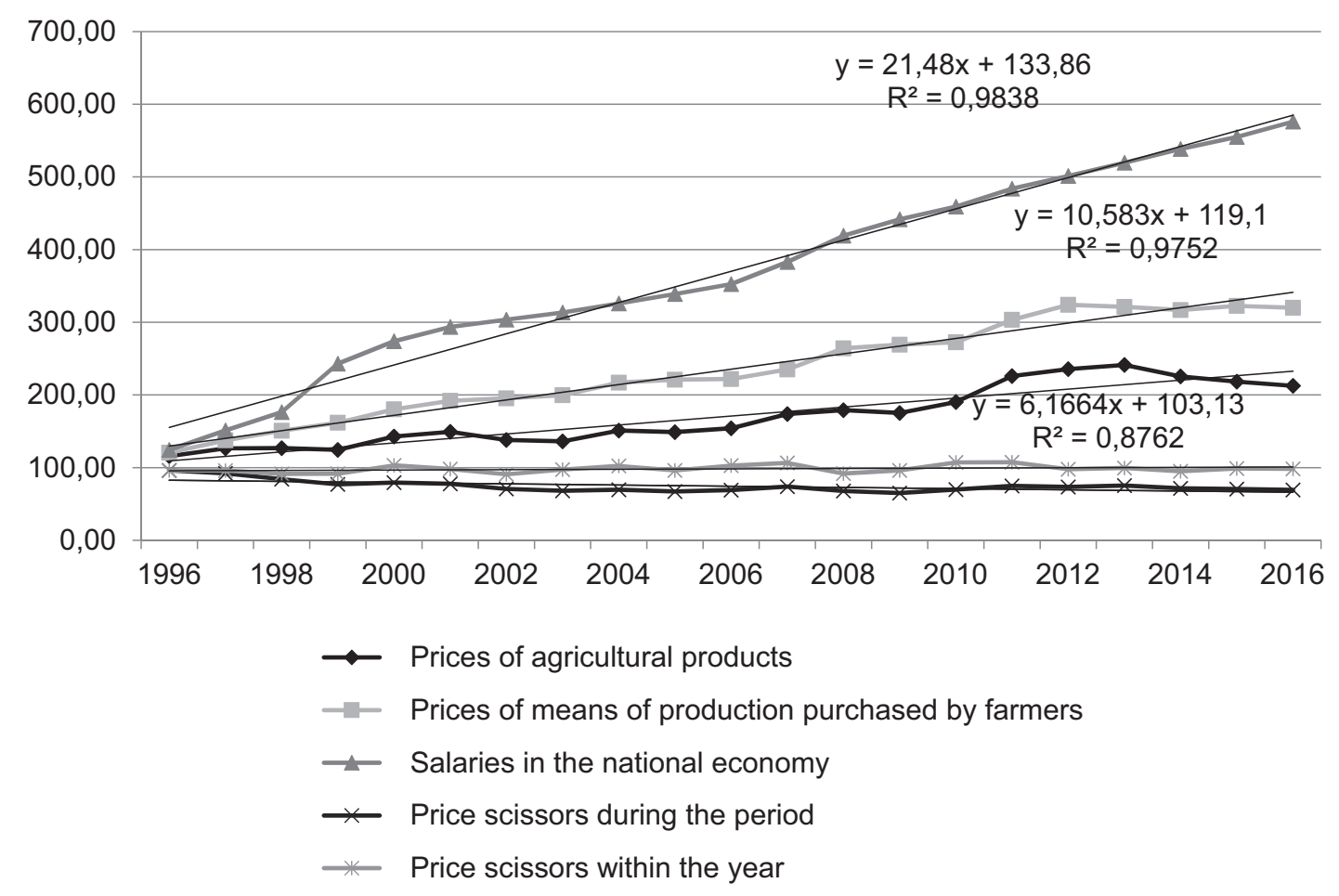

Figure 1. Trends in the evolution of labour costs in the national economy, prices of means of production for agriculture and prices of agricultural products in Poland between 1995-2016

Source: Ziętara and Adamski (2018). 


\section{OBJECTIVE OF THE PAPER, SOURCES OF MATERIALS AND METHODOLOGY}

The objective of the paper is to assess the share of larger farms in several areas: the number of farms, the use of agricultural land, employment and production and also to assess land and labour productivity when compared to the average level of these indicators. The subject of the studies are larger farms from selected European Union countries. The assessment covered farms with the following area: 30-50; 50-100 and 100 ha or more of UAA. The area of 30 ha, as the lower limit, was adopted conventionally, following existing trends. The studies covered farms from two groups of selected countries differing in economic development level specified by GDP per capita in 2014. The first group included countries with a GDP per capita exceeding EUR 30 000. In contrast, the second group with low GDP included countries where GDP was within the range of EUR 5.9 to 18.1 thousand per capita.

The adoption of this criterion resulted in the fact that Group 1 included the EU-15 countries (the 'old' EU) while Group 2 - the countries which joined the EU in 2004 and later. By adopting GDP as a criterion for the selection of countries to be analysed, the relationship between the country's economic development level and the economic strength of farms has been followed (Sikorska, 2013). The list of the analysed countries is shown in Table 1.

Table 1. Gross domestic product per capita and average farm size in the analysed countries in 2014

\begin{tabular}{|c|c|c|c|c|c|c|}
\hline \multirow{19}{*}{ GDP } & \multirow{10}{*}{ high } & Country & $\begin{array}{c}\text { GDP } \\
\text { (EUR thous. per } \\
\text { capita) }\end{array}$ & $\begin{array}{c}\text { Farm area } \\
\text { averaged } \\
\text { (ha) }\end{array}$ & $\begin{array}{c}\text { SO in } 2013 \\
\text { (EUR thous. per } \\
\text { farm) }\end{array}$ & $\begin{array}{c}\text { Farm size* } \\
\text { averaged }\end{array}$ \\
\hline & & Denmark & 47.0 & 67.5 & 250.2 & large \\
\hline & & Sweden & 46.6 & 45.2 & 69.7 & medium large \\
\hline & & Ireland & 41.9 & 35.5 & 35.9 & medium small \\
\hline & & the Netherlands & 39.3 & 27.4 & 303. & large \\
\hline & & Austria & 38.7 & 19.2 & 40.4 & medium small \\
\hline & & Germany & 36.1 & 58.6 & 162.3 & large \\
\hline & & Belgium & 35.9 & 34.6 & 226.6 & large \\
\hline & & Great Britain & 35.0 & 93.6 & 119.2 & large \\
\hline & & France & 32.3 & 58.7 & 120.5 & large \\
\hline & \multirow{9}{*}{ low } & Slovenia & 18.1 & 37.7 & 13.9 & small \\
\hline & & Czech Republic Republic & 14.9 & 132.8 & 169.4 & large \\
\hline & & Slovakia & 14.0 & 80.6 & 79.9 & medium large \\
\hline & & Lithuania & 12.5 & 16.7 & 11.2 & small \\
\hline & & Latvia & 10.7 & 23.0 & 12.1 & small \\
\hline & & Poland & 11.2 & 10.1 & 15.2 & small \\
\hline & & Hungary & 10.6 & 9.5 & 11.3 & small \\
\hline & & Romania & 7.6 & 3.6 & 3.3 & very small \\
\hline & & Bulgaria & 5.9 & 18.3 & 13.1 & small \\
\hline
\end{tabular}

* Farm size adopted according to FADN.

Source: Statistisches Jahrbuch über Ernährung, Landwirtschaft und Forsten (2015). 
Group 1 is dominated by larger, medium-large and large farms. Group 2 - by very small and small farms. The exceptions are farms in the Czech Republic and Slovakia, large and medium large, respectively. The studies covered the years 2005 and 2016. This period makes the analyses of the dynamics of changes possible. The studies used the comparative method. The source of study materials was statistical data contained in statistical yearbooks and Eurostat ${ }^{4}$.

\section{CHANGE IN THE ROLE OF LARGER FARMS IN LAND USE AND AGRICULTURAL PRODUCTION IN 2005 AND 2016}

The studies conducted led to the following results (Józwiak, Mirkowska and Ziętara, 2018). In the analysed years, 2005 and 2016, in all analysed countries, a decrease in the total number of farms was observed. In Group 1 countries, the number of farms ranged from $-5 \%$ (Great Britain) to $-17 \%$ (Sweden). In Group 2 countries with low GDP per capita, the decrease in the number of farms was larger and ranged between $-9.4 \%$ (Slovenia) to $-62.5 \%$ (Slovakia). A consequence of the decrease in the number of farms has been an increase in average area. In Group 1, it was between 5.3\% (Austria) and 61.0\% (Great Britain). In Group 2, this increase was higher, from $11.1 \%$ (Slovenia) to $331.8 \%$ (Bulgaria). The area of farms in Group 1 was by far larger than in Group 2, with the exception of the Czech Republic and Slovakia. In most countries in Group 1, there was a decrease in the share of farms with an area of 30-50 ha in total. The exceptions were: Austria, the Netherlands, Germany, Belgium and Great Britain. In the second group, there was an increase in the share of this class of farms in overall and an increase in number, with the exception of Lithuania and Latvia.

In the farm class 50-100 ha, in Group 1, there was an increase in share in the total number, excluding Denmark, Sweden and France, while reducing their number. In Group 2, all countries were characterised by an increase in share of this class of farms in total as well as an increase in number.
In the class of farms of 100 ha and more, all countries showed an increase in share in the total number of farms and an increase in number. The reverse situation was in Austria where an increase in the share involved a decrease in the number of farms.

During the analysed years, there were changes in the share of the individual size classes of farms in land use. In Group 1 countries, there was a decrease in the share of farms with an area of 30-50 ha in land use. The exception was Austria. In Group 2, the share of this class of farms in land use increased, except for Lithuania and Latvia. In the farm class of 50-100 ha of UAA, in Group 1 there was a decrease in land use, except for the Netherlands, Austria and Belgium. In Group 2, the share of this class of farms in land use increased. In the class of farms of 100 ha and more, in Group 1, share in land use increased, except for Austria. In 2016, the share of those farms in land use ranged from $17.9 \%$ (Austria) to $74.6 \%$ (Great Britain). In Group 2, the share of this class of farms in land use increased, except for the Czech Republic and Slovakia, where the share was very high and in 2016 , amounted to 87.5 and $88.6 \%$, respectively. In Group 1, there was an increase in average farm area with the exception of the Netherlands, Austria and Germany. The average farm area in this class ranged between 152.5 ha (the Netherlands) and 311.4 ha of UAA (Great Britain). In Group 2, apart from Latvia and Bulgaria, there was a decrease in average farm area. In 2016, the average farm area ranged from 276.6 ha (Lithuania) to 697.6 ha (Slovakia).

The share of employees in farms of 30-50 ha in the total number of agricultural employees in Group 1 decreased in the analysed years, while in Austria and all Group 2 countries it increased. In both groups, there was a decrease in employment per 100 ha of UAA. This was stronger in Group 2. Similar trends occurred in the class of farms of 50-100 ha. In the class of farms of 100 ha or more, in both groups, there was an increase in total employment share. The exceptions were Sweden and Ireland, from Group 1, and the Czech Republic from Group 2. In most countries, both groups experienced a decrease in employ-

${ }^{4}$ Eurostat website http://ec.europa.eu/eurostat/data/database [Accessed 24.04.2018]. 
ment per 100 ha of UAA, and was stronger in Group 2. Despite this, the level of employment in Group 2 countries was about twice as high than in Group 1.

In the analysed years, in Group 1, the share of farms from the class $30-50$ ha, when it comes to the total agricultural production, decreased. The exceptions were Austria and the Netherlands. In Group 2, apart from Latvia, the share of this class of farms in production increased. In both groups, the production level per farm increased. The trends were similar for farms of 50-100 ha. The exceptions were Denmark, Sweden, Great Britain and France from Group 1 and Slovakia, from Group 2, where there was a decrease in the share of this class of farms in total production. In this class of farms, there was also an increase in production value per farm. The exceptions were Denmark and Slovakia. In the class of farms of 100 ha and more, in all countries, there was an increase in share in total production. In Group 1 countries like Denmark, Sweden and Great Britain, this share exceeded $60 \%$. In Group 2 countries, the largest share was observed in the Czech Republic, Slovakia and Bulgaria, where it was $78.8,79.5$ and $62.1 \%$, respectively.

There were significant differences in land productivity, between Group 1 and 2: in Group 1, it was about twice as high. In the class of farms of 30-50 ha, in Group 1, land productivity was lower than the average in those countries. The exceptions were Austria, Germany and France. In Group 2, land productivity was similar to the average. In farms of 50-100 ha and 100 ha or more, land productivity was lower than the average in both analysed years.

Labour productivity in all farms in Group 1 was by far larger than in Group 2. In 2005, in farms with the lowest productivity in Group 1, it was 8.3 times higher than the similar productivity in the second group and in farms with the highest productivity it was 7 times higher than in Group 2. The respective values in 2016 were 4.5 and 4.0. Labour productivity in farms of 30-50 ha in Group 1, with the exception of the Netherlands, was lower than the average. On the other hand, in Group 2, it was higher than the average except for the Czech Republic. In the class of farms of 50-100 ha only Denmark and Sweden noted labour productivity lower than the average. In the class of farms of 100 ha or higher, labour productivity was higher than the average in all countries. The labour productivity differences between Group 1 and 2 in this class were smaller. The analogous figures for 2005 were 2.4 and 2.7 and for 2016: 2.5 and 4.3.

\section{CONCLUSIONS}

1. The processes of adaptation of farms to variable farming conditions, irrespective of the economic development level in the countries, consisted of an increase in the production scale, by increasing the farm area and increasing the production intensity level.

2. In some Group 1 countries with a higher GDP level (Denmark, Sweden, Great Britain and France), the share of farms of 30-50 and 50-100 ha, when it comes to the number of farms, land use and production, decreased. They became auxiliary farms.

3. In all the analysed countries, the share of farms of 100 ha and more in land use and production increased in the years 2005-2016. In most countries, the share in production exceeded $50 \%$.

\section{REFERENCES}

1. Brinkmann, T. (1922). Die oekonomik des landwirtschaftlichen Betriebes. Grundriss der Sozialoekonomik. Mohr-Siebeck: Tübingen.

2. GUS (2017). Charakterystyka gospodarstw rolnych w 2016 roku. Dział Wydawnictw Statystyczny GUS, Warszawa.

3. Józwiak, W. (2013). Polskie rolnictwo i gospodarstwa rolne w pierwszej i drugiej dekadzie XXI wieku. Publikacje Programu Wieloletniego 2011-2014, 53.

4. Józwiak, W., Mirkowska, Z. and Ziętara, W. (2018). Larger farms in Poland and in the selected European Union countries in the years 2005 and 2016 [typescript]. IERiGŻ-PIB, Warszawa.

5. Kuś, J., Matyka, M. (2014). Zmiany organizacyjne $\mathrm{w}$ polskim rolnictwie $\mathrm{w}$ ostatnim 10 -leciu na tle rolnictwa UE. Zagadnienia Ekonomiki Rolnej, 4, pp. 50-67.

6. Sikorska, A. (2013). Transformations in the agrarian structure of individual farms. IERiGŻ-PIB, Warszawa.

7. Statistisches Jahrbuch über Ernährung, Landwirtschaft und Forsten (2015). Landwirtschafts, Münster.

8. Steffen, G. (2001). Size and organisation of family farms in Germany. Wydawnictwo SGGW, Warszawa.

9. Wąs, A., Marzewska, S. (2012). Przemiany strukturalne 
Proceedings of the 2018 International Scientific Conference 'Economic Sciences for Agribusiness and Rural Economy' No 1, Warsaw, 7-8 June 2018, pp. 28-33

w rolnictwie w wybranych krajach europejskich. Roczniki Ekonomii Rolnictwa i Rozwoju Obszarów Wiejskich, 99 (4), pp. 75-88.

10. Wigier, M. (2013). Model rozwoju rolnictwa polskiego w świetle efektów realizacji WPR. Zagadnienia Ekonomiki Rolnej, 1, pp. 22-41.
11. Woś, A. (ed.) (1998). Encyklopedia agrobiznesu. Fundacja Innowacja, Wyższa Szkoła Społeczno-Ekonomiczna, Warszawa.

12. Ziętara, W., Adamski, M. (2018). Competitiveness of Polish dairy farms. Zagadnienia Ekonomiki Rolnej, 1, pp. 56-79. 